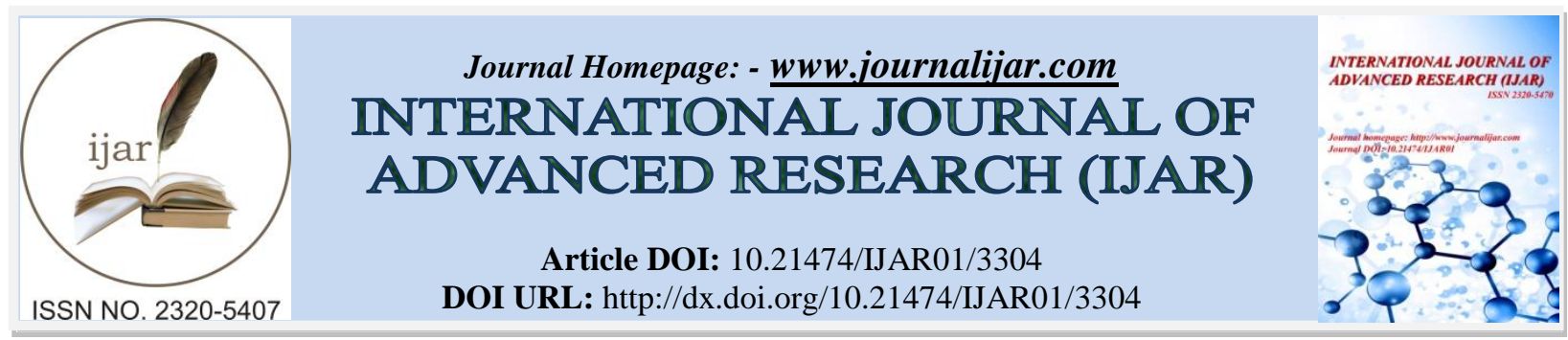

RESEARCH ARTICLE

\title{
STUDYING STRATEGIES TO EXPLAIN STRUCTURE AND ORGANIZING PRODUCT DEVELOPMENT AND DESIGN ORGANIZATIONS WITH OPEN INNOVATION VIEW.
}

Mehdi Nikfarjam ${ }^{1}$, Hossein Aghaei Ata ${ }^{2}$, Ebrahim Mohammadi Pirlar ${ }^{2}$ and Mojtaba Kheyrinejad ${ }^{2}$.

1. Asst. Prof. Department industrial engineering, Islamic Azad University North Tehran Branch, Tehran, Iran.

2. Ph.D Student Department industrial engineering, Islamic Azad University North Tehran Branch, Tehran, Iran.

\section{Manuscript Info}

Manuscript History

Received: 25 December 2016

Final Accepted: 25 January 2017

Published: February 2017

Key words:-

development and design, open

innovation, structure and organizing.

*Corresponding Author:

Hossein Aghaei Ata

\section{Abstract}

In recent years, open innovation has been changed to one of the issues regarded by innovation management. Product development and design (PD\&D) organization is a capacity and capability which is able to take an action to convert idea to the product in its own processes. One of the most important management decisions in development and design cycle is to make a decision about this issue that how employees are organized and grouped and how their relationship would be. In this paper, investigating organizational structure and form of PD\&D organizations which have an especial importance have been taken into consideration. In the following, owing to the open innovation approach, these organizations are investigated and proper strategies are propounded and then organizational structure proportioned to product lifecycle is proposed.

Copy Right, IJAR, 2017,. All rights reserved.

\section{Introduction:-}

Today, by curtailing lifecycle of goods and their applied technologies, innovation issue has found an increasing importance in the commerce [1]. But in today's dynamic and developed environment, innovation is not being done in organizations, but also it has dissimilated beyond the organization's borders. Therefore, organizations are looking for knowledge, information and external partners as the valuable resources of innovation. Recently, a change has been observed from innovation traditional model which is fundamentally focusing on internal development and research toward open innovation [2].

One of the factors which collapse close innovation logic can be pinpointed as increase in replacement of skilled and experienced people, stepped-up trend of academic education, increasing role of private venture capitalists, continuous increasing of customers' and suppliers' knowledge as well as curtailing technology lifecycle [3]. In contrast, close innovation which considers success dependent on exerting control and asks organizations to create ideas by their own; then develop themselves; fabricate; take to the market; hand out; finance and provide after selling services [3]. Open innovation asks the organization to employ external ideas like internal ideas [4]. Henry Chesbrough defines open innovation as "Open innovation is a pattern based on this assumption that if companies intend to promote their technology level, they can and must take an advantage of external technological ideas like their internal ideas and use diverse internal and external ways toward market" [3].

Corresponding Author:- Mehdi Nikfarjam.

Address:- Asst. Prof. Department industrial engineering, Islamic Azad University North Tehran Branch,

Tehran, Iran. 
Fast-pace changes and development in technology area, increase in innovation costs, increasing competitiveness in introducing new products to the market and curtailing lifecycle of products and technologies will lead to enhance in organization's needs to interact with the environment and external beneficiaries via opening organization's borders in order to interact innovative ideas [5]. Reduction in cost and time of new product development, increasing product quality, creating new income resources derived from selling waste technologies not used by the organization and also founding spin-off companies are effects which are resulted through following this approach [6].

In virtue of today's world changes and developments and inevitability of employing open innovation approach, organizations ought to take some strategies by profiting from opportunities created by this view in order to use benefits created by it. That's why; detecting necessities to implement open innovation can be considerably helpful for organizations.

Mortara et al (2009) in a dissertation have studied how to implement open innovation in giant multinational companies. According to their enquiry, changing structures, skills, stimuli and control methods is aiding organization with creating open innovation-supportive culture [7].

Chiaroni et al (2010) have investigated structural changes in transiting from the close innovation to open innovation in four Italian enterprises. In keeping with Rmnakys and Bdyan (1999) which have studied organizational change literature have arrived at this conclusion that open innovation as an organizational change process is carried out via sequences of freezing out-move-institutionalization which are 3 fundamental phases of changing. According to their research, in a travel from close innovation to open innovation, 4 underlying dimensions which are involved are: networks, organizational structure, and evaluation process and knowledge management system [8]. Parid et al (2011) have introduced 3 key areas which have been regarded by organizations in order to exert open innovation. These three areas are: people, process and technology [9]. Ades et al (2013) have investigated conducting open innovation in organizations of nach VRA, IBM and Siemens. According to their study, implementing open innovation in the organization requires development of activities to resolve necessity requirements to exert open innovation. These requirements are: organization's culture, dexterity of people involved in activities related to open innovation and their motivation to achieve pertinent results via applying open innovation [10]. Based on the carried out studies in this area, detected requirements to be transited from close innovation to open innovation in PD\&D organizations are: Processes, Organizational structure, Networking as well as KM system. In this paper, studying structure and organizing PD\&D organizations with open innovation view and crucial factors of organizations' success have been taken into consideration.

\section{Bases of architecture structure of PD\&D organizations:-}

Organizational key challenges are to compromise distinction and integration. Creative activities required organizational structures and managerial systems are different with operational activities whereas development of new products and implementing new activities need integrity of creativity and expertise in technology in tune with production capabilities, marketing, budgeting, distribution and customer support. Gaining such integrity is hard. Fulfilling competitive advantage in elaborate and unpredictable environment of business necessitates this issue that company compile economies of scale along with entrepreneurial flexibility, innovation along with cost efficiency and globalization along with a real responsiveness. This issue creates new challenges for organizational structure designs and management systems whereas an integrated approach to formulate and implement strategy owing to their reciprocate dependencies have been propounded. Basis of structure architecture of each organization has to be the mission and tasks assigned to each organization. Since in this paper, structure architecture of product development and designing company is approached, it is necessary to firstly scrutinize the task of product design and development organization.

PD\&D organization undertakes the mission of fulfilling the system from an idea to the initial sample or criterion sample. In another word, PD\&D organizations have the duty to receive requirements of the senior PD\&D organization (Employer) and by exerting all of capacities of supplier network in and out of the organization, fulfill the product which meets respective need. Accomplishing a product is feasible through conducting design project. Designing project has some steps and architecture of designing process tailored to each company is different.

\section{Designing process:-}

The main purpose of this process is to profit from external knowledge. This process helps with creating organization's relationship with external people or organizations by aiming to achieve technical and scientific competencies in order to progress organization's innovation [11]. 
To architect designing process, there are various models and approaches such as waterfall, spiral and V models and so on which are applied tailored to complexity level of product and readiness level of development and design team. Proportionated to these conceptions, it is offered that V model has been considered for PD\&D. In the following pic, $\mathrm{V}$ model has been formed for the steps of project lifecycle. On this basis, in this paper, structure of PD\&D organizations is architected in a way that simultaneously implements both implementation process of PD\&D project (The first mission) and engineering designing process (The second mission).

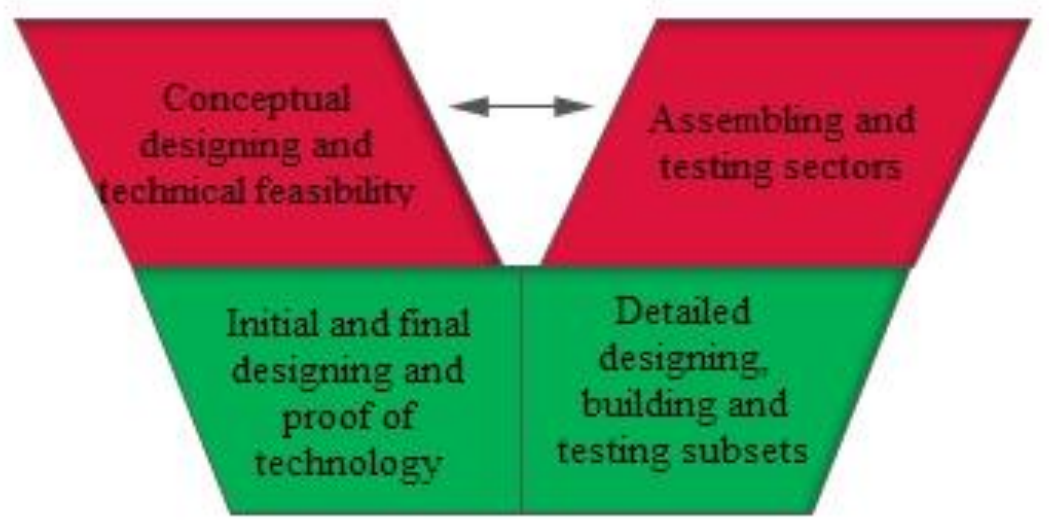

Fig 1:- V model proposed for steps of PD\&D project

\section{Structures of PD\&D organizations:-}

To manage organization's external knowledge successfully, it is required to assign organizational structure which facilitates achieving external knowledge and its integrity with organization's innovation process. Such structure is required also for proposing organizational internal ideas to the organizational external environment. Organizational structure required for applying open innovation includes: organizational unit, open innovation-supportive organizational roles and education and stimuli tailored to open innovation [12]. Structure of PD\&D organization has to be firstly responsive to project lifecycle activities. Moreover, requirement relevant to product lifecycle also has to be considered. At the first step, the structure needed for PD\&D organization to accomplish implementation process of designing project is architected. In fig 2, steps of product designing project and their relationship with open innovation approach (Outsourcing) have been portrayed.

\section{These steps are:}

1. Macro designing and technology feasibility

2. Conceptual designing and technical feasibility

3. Initial and final designing and proof of technology

4. Detailed designing, building and testing subsets.

5. Assembling and testing sectors

6. Integrating product and final tests.

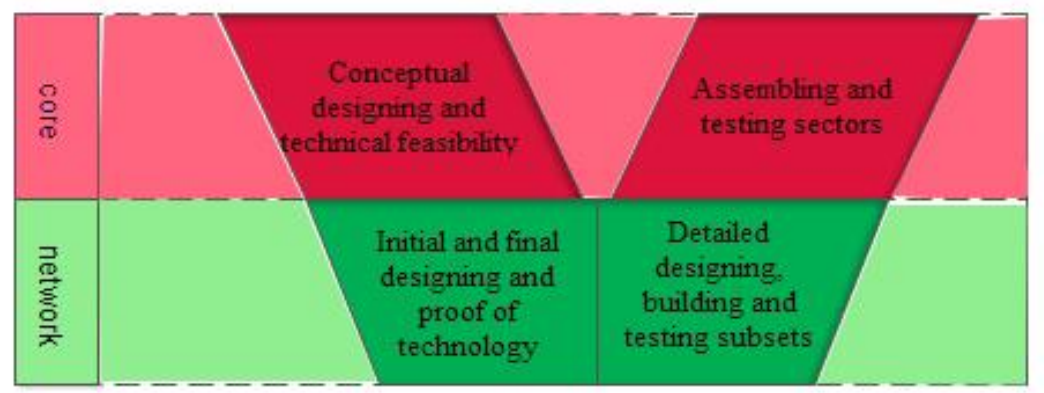

Fig 2:- The relationship between designing steps of the conception of open innovation view 


\section{PD \& D organizational units:-}

Open innovation practices are carried out by organizational units. Thus, creating independent business unit of open innovation to simplify and make effective knowledge process from external players to internal ones is very crucial. Also, creating business development unit and allocating adequate resources and skills is mostly requiring effective exploiting of owned technologies [13]. Organizational units can be centralized (All projects is managed by centralized control units), decentralized (Each unit has a sector related to the project for itself) or hybrid (A combination of centralized and decentralized) [14]. Due to this issue that there is a wide range of diverse organizational units which are potential can be involved in open innovation, 7 organizational units which are important for implementing innovation are: research and development, process and product development, marketing, production management, supplies, subsidiaries (Contractors) and human resource management [15].

By pondering in designing steps, it can be found that it can be taken an action to break down steps of product designing project so that each activity can be placed in a technical area. Activities can be classified into technical categories including product engineering, manufacturing engineering and test engineering. Another distinction which makes a statement is this issue that activities are based on technology or product. This distinction is in fact the same as the area of outsourcing mission. In this dissertation, based on our underlying approach, activities of core area are serviced from tasks of PD\&D organizations and activities of network area are serviced from companies out of the organization. In summary, the results of this classification are brought in the following. Technical area of each activity has been inserted in the bracket and its relationship to the project steps has been inserted in the arc:

1. Technical feasibility and conceptual designing (1) [System];

2. Initial designing (2-A) [technology];

3. Proof of technology (2-B) [technology];

4. Final designing (2-C) [technology and system];

5. Detailed designing of subsystems (3-A) [Technology];

6. Building subsystems (3-B) [Technology];

7. Subsystems test (3-C) [Technology];

8. System assembly (4-A) [system];

9. System test (4-B) [system];

Thus to cover steps of project lifecycle, the following units have to be placed in PD\&D organizations. Role of each unit based on open innovation view is as the following:

* Product designing unit: This unit has responsibility for doing 2-A and 1. Receiving 2-A step from contractors is undertaken by this unit. In other steps, it is playing the role of observer and corroborant.

- Manufacturing unit: This unit undertakes 4-A activities. Receiving 2-B, 3-A and 3-B from contractors is done by this unit. In other steps, it is playing the role of observer and corroborant.

* Simulation and test unit: This unit has responsibility for doing 4-B. Receiving 2-B and 3-C from contractors is undertaken by this unit. In other steps, it is playing the role of observer and corroborant.

* Technical support and supply unit: Receiving support and supply requirements of subsets from contractors in step 3-C is undertaken by this unit. Also, accomplishment and rendering requirements of product support and supply for employer in step 4-B is undertaken by this unit too.

In fig 3, a model of units of PD\&D organizations has depicted. The main axis of a project is designing unit which is accounted as the heart and center of innovation in the organization. What has surrounded all activities of a project and will lead to retain integrity of all activities is governance and management area of PD\&D organization. By exerting structure of DSM designing matrix, interfaces related to the practices pertinent to different units of PD\&D organizations can be scrutinized and in compliance with organization's mission, it can be formulated. 


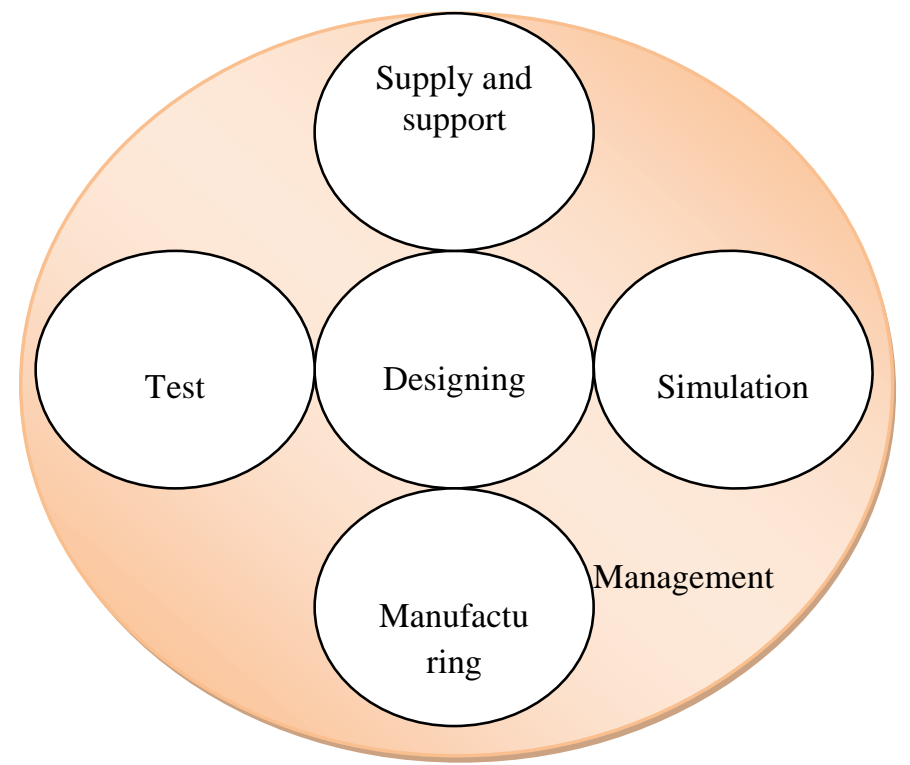

Fig 3: Working branches of PD\&D organizations

Networking provides collaborative and interactive space. Evidences show that PD\&D organizations with open innovation view require creating a vast network of inter-organization communication with some of external roles especially universities and research institutes, suppliers and users [13].

Creating a heterogeneous network of diverse partners also suppliers, customers, consultants, opponents, universities as well as public and private research institutes enhance innovation performance of an organization, because networking approach toward innovation will lead to synergy [15].

Features of innovation networks can be detected by 2 variables of quest vastness and quest depth. Quest vastness indicates the number of external resources or research channels in which PD\&D organizations are dependent on. Quest depth is the rate that organization receives information from different external resources or research channels [16].

Organizational structure is a method or path in which organizational activities are divided, organized and coordinated [17]. Structure is an outcome of a combination of the relationship between organizational elements which forms the existence philosophy of activities [18]. Organizational structure enunciates levels existed in administrative hierarchy and determines control domain of managers or supervisors. Also, organizational structure determines people who are working in different departments in the group and grouping or classifying departments which are existed in the whole of organization. Plus, this organization's structure encompasses designs of the systems by which activities of all departments are coordinated and integrated and thereby effective relationship system in the organization will be guaranteed [19].

Another important point which has to be considered in structure architecture is fulfilling conception of concurrent engineering and conception of design for product lifecycle. Hence, it is necessary that plus project lifecycle, product lifecycle and its pertinent requirement are also considered. After expressing required strategies to cover organizing's requirements pertinent to project steps, it is turn to consider required arrangements for designing structure. In basic research step, strategy specific for technical structure has to be adopted, because there is also a need there for low coordination and relatively high flexibility and in engineering development step, project structure is drawn, because need for coordination is reaching the highest point and need for flexibility is diminishing. Requirement for using matrix structure is arisen for product development step. That's why; here there is a need for high coordination and relatively high flexibility. Also in phases of engineering services and production, technical or matrix structure can also be applied. Selecting organizational structure is the function of the management needs rate for coordination and flexibility. In fig 4 , the place of designing project lifecycle in product lifecycle, structure and organizing PD\&D organization have been displayed. 


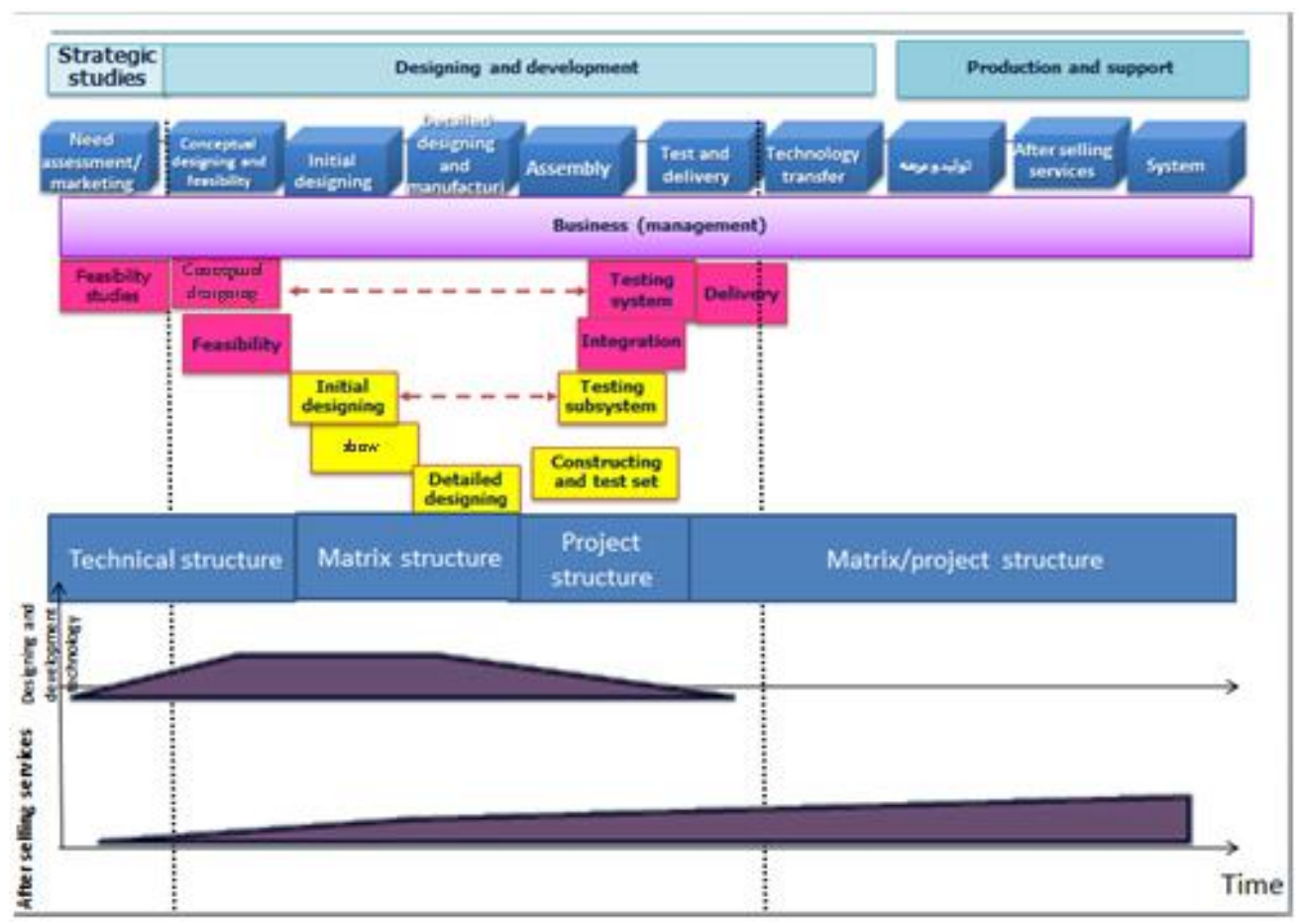

Fig 4:- The place of designing project lifecycle in product lifecycle and human resource and time allocation

Totally, none of the structures can be known as problem- solving of all sorts of PD\&D organizations and then, contingency approach in choosing appropriate structure for each organization is recommended.

\section{Conclusion:-}

Organizing design and development organization is not a simple issue but also it is a complex and considerable issue. Organizations have to be able to fast convert each idea in their process to the product. Each organization must have an appropriate structure owing to product lifecycle in order to have reaction ability and proper responsiveness to customer needs in the certain time. By this approach and picking out $\mathrm{V}$ method for PD\&D, designing process time in complex products has been diminished more than $40 \%$ and designing risk and product development have got close to zero.

It is recommended that for forthcoming researches, $\mathrm{W}$ model is investigated and organizational structure and project underlying activities due to the model and open innovation view is studied and researched.

\section{Acknowledgement:-}

Because of applying data and results used in this paper, Mr Ali Akbar Dastanpour Housein Abadi is greatly appreciated.

\section{References:-}

1. Jacobides M.G, Billinger S. Designing the boundaries of the firm: from "make, buy, or ally" to the dynamic benefits of vertical architecture. Organization Science 2006; 17 (2), 249-261.

2. Geum Y, Kim J, Son C, Park Y. Development of dual technology roadmap (TRM) for open innovation: structure and typology. Journal of Engineering and Technology Management 2013; (30), 309-325.

3. Chesbrough, H. Open Innovation: The New Imperative for Creating and Profiting from Technology. Harvard Business Press. 2003.

4. Monsef S, Ismail W.K.W. The impact of open innovation in new product development process. International Journal of Fundamental Psychology \& Social Sciences 2012; 2(1), 7-12.

5. Felin, T., Zenger, T.R. Closed or open innovation? Problem solving and the governance choice. Research Policy. (2013). 
6. Ades C, Figlioli A, Sbragia R, Porto G, Plonski G, Celadon K. Implementing open innovation: The case of Natura, IBM and siemens. Journal of Technology Management \& Innovation 2013; 8, 12-25.

7. Mortara L, Napp J, Slacik I, Minshall T. How to implement open innovation: Lessons from studying large multinational companies. University of Cambridge 2009.

8. Chiaroni D, Chiesa V, Frattini F. Unravelling the process from closed to open innovation: evidence from mature, asset-intensive industries. R\&D Management 2010; 40 (3), 222-245.

9. Parid V, Larsson T.C, Lsaksson O, Oghazi P. Towards open innovation practices in aerospace industry. International Conference on Research into Design (ICoRD '11) 2011; Bangalore, India, January; 10-12.

10. Ades C, Figlioli A, Sbragia R, Porto G, Plonski G, Celadon K. Implementing open innovation: The case of Natura, IBM and siemens. Journal of Technology Management \& Innovation 2013; 8, 12-25.

11. ]. Bahemia H, Squire B. A contingent perspective of open innovation in view product development projects. Druid summer conference on opening up innovation: strategy, organization and technology 2010; London, England, June: 16-18.

12. ]. Mortara L, Napp J, Slacik I, Minshall T. How to implement open innovation: Lessons from studying large multinational companies. University of Cambridge 2009.][ Chiaroni D, Chiesa V, Frattini F. Unravelling the process from closed to open innovation: evidence from mature, asset-intensive industries. R\&D Management 2010; 40 (3), 222-245.

13. Chiaroni D, Chiesa V, Frattini F. The Open Innovation Journey: How firms dynamically implement the emerging innovation management paradigm. Technovation 2011; 31, 34-43.

14. Waiyawuththanapoom N, Isckia T, Danesghar F. Ready for open innovation or not? An open innovation readiness assessment model (OIRAM). Proceeding of the International Conference on Intellectual Capital 2013; Washington, USA, October 24-25

15. Bahemia H, Squire B. A contingent perspective of open innovation in view product development projects. Druid summer conference on opening up innovation: strategy, organization and technology 2010; London, England, June: 16-18.

16. Laursen K, Salter A. Open for innovation: The role of openness in explaining innovation performance among U.K. manufacturing firms. Strategic Management Journal 2006; 27, 131-150.

17. Aarabi, S.M., 1997- Designing organizational structure, cultural research bureau

18. Bunge, M., 1976- A world of systems. Reidel, Dordrecht

19. Daft, R.L., 1991- Organization Theory and Design, Third Edition: West publishing company.

20. Chesbrough H, Brunswicker S. Managing Open Innovation in Large Firms. Survey Report | Executive Survey on open Innovation 2013. Germany: Fraunhofer IAO. 